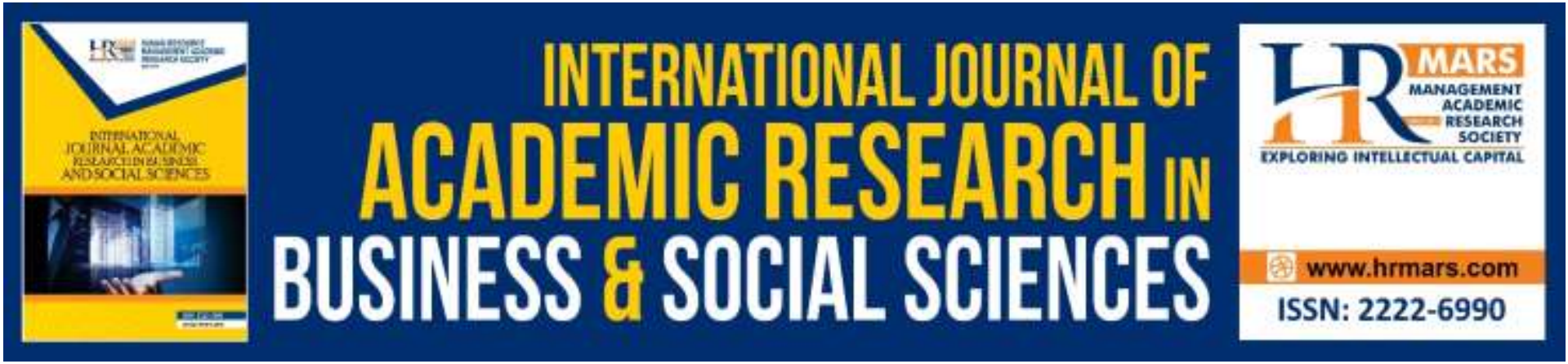

\title{
Application Technology: Literary Medium through Smartphone
}

\author{
Rosnidar Ain
}

To Link this Article: http://dx.doi.org/10.6007/IJARBSS/v9-i8/6232

DOI: $10.6007 /$ IJARBSS/v9-i8/6232

Received: 10 May 2019, Revised: 10 June 2019, Accepted: 10 July 2019

Published Online: 09 August 2019

In-Text Citation: (Ain, 2019)

To Cite this Article: Ain, R. (2019). Application Technology: Literary Medium through Smartphone. International Journal of Academic Research in Business and Social Sciences, 9(8), 163-172.

Copyright: @ 2019 The Author(s)

Published by Human Resource Management Academic Research Society (www.hrmars.com)

This article is published under the Creative Commons Attribution (CC BY 4.0) license. Anyone may reproduce, distribute, translate and create derivative works of this article (for both commercial and non-commercial purposes), subject to full attribution to the original publication and authors. The full terms of this license may be seen at: http://creativecommons.org/licences/by/4.0/legalcode

Vol. 9, No. 8, 2019, Pg. 163 - 172

http://hrmars.com/index.php/pages/detail/IJARBSS

JOURNAL HOMEPAGE

Full Terms \& Conditions of access and use can be found at http://hrmars.com/index.php/pages/detail/publication-ethics 


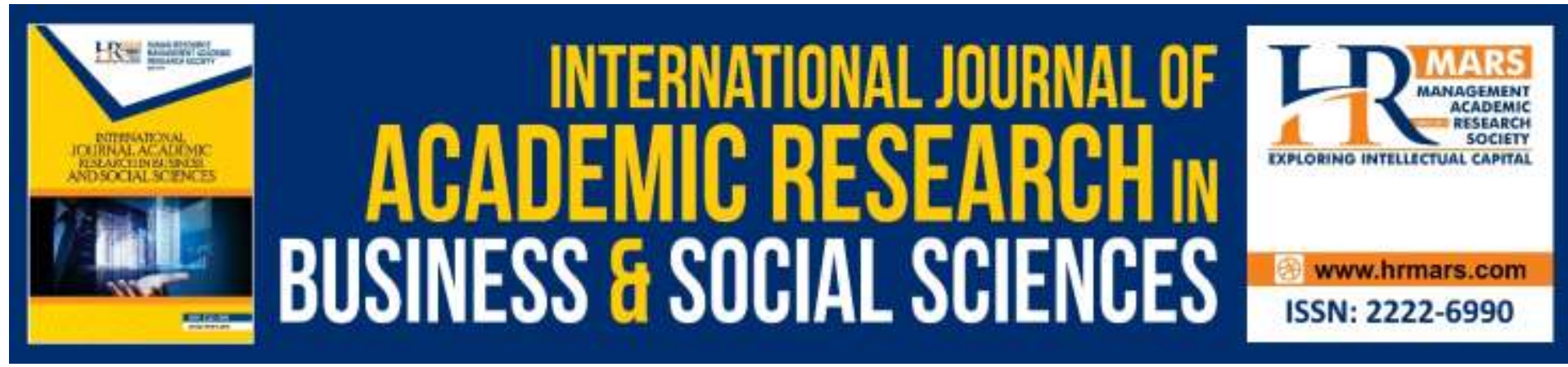

\title{
Application Technology: Literary Medium through Smartphone
}

\author{
Rosnidar Ain \\ School of Humanities Universiti Sains Malaysia \\ Email: rosnidarain@usm.my
}

\begin{abstract}
Technology enables various tasks and situations to become easier, faster and they reach wider network as well. It also makes impossible things materialize and become a reality. Now, technology has infiltrated every nook and cranny of a human's life. In the past, it was believed that literature could not be adapted to technology. Nevertheless, technology is required to create a wider space, in a faster and easier method in order to propel literature into greater heights. Slowly, the older way of appreciating literature is no longer suitable to be kept for a prolonged duration of time. With the emergence of smartphones, numerous applications are developed to ease a poet or an author in their quest to produce literary materials in the form of the latest literature. This study will discuss the use of smart phones' applications which serve the authors in the process of producing poems or short stories
\end{abstract}

Keywords: Technology, Smartphones, Applications, Literature, Literary Materials.

\section{Introduction}

Malaysia has its own esteemed prolific authors and poets who have garnered highest accolades in the field of literary writing. These authors were not born into the frenzy of technology instead, they used typewriters and information was not at their fingertips and yet, they were able to come out with quality literary texts which last for so long. Unfortunately, those days are gone and replaced by many kinds of technology that enables humans to easily carry out their activities, obtain information and be creative. Even though the Internet has taken over almost every aspect of daily life, the process is rather slow when it involves literature. The change from Electronic Galaxy to Digital Galaxy has left a huge mark in all circumstances. Social Media, smartphones and many applications are used to assist the development of literature. In the process of creating a literary text, various techniques and technology are used to produce one that draws a lot of readers. Despite the sluggish acceptance of technology among the society, it is gradually gaining trust and acceptance.

The creation of a literary work has changed from time to time. In the past, producing literary work was limited to those in the form of texts only. However, authors or poets today have begun to utilize latest technology to gain more interest among the public on their work. In writing a novel, for instance, the author experimented with links, hypertexts or multimedia elements such as sounds, graphics, animation and videos to give a difference as well as 
attraction on their work. Literary work is no longer dependent on textual elements in the form of conventional or printed material. In poetry writing, for example, the multimedia elements are often used to give an impact on certain poems: poets could add sad or happy audio, background sounds such as waves, birds, rain and others to add emotions to a compilation of poems as featured in Electronic Literature $\mathrm{Vol} 1$ to 3 (refer to http://collection.eliterature.org).

However, the creation of a literary work demands a high level of expertise in using computer technology. Previously, any work that was published in the form of multimedia must be given adequate software to function. Nevertheless, the introduction of applications in the digital arena has enabled the readers to use more reliable application to replace other difficult and detailed software. Today, application (or apps)) have been accepted as part of the technology that makes it easier for the user to write something that is interesting, aesthetically pleasing and fast, thanks to the features in the applications that offer various functions and utilization.

Based on their functionality, this study focuses on the benefits of applications in smartphones which are related to literature to provide knowledge and alternative ideas to authors in their efforts to produce digital-based literary work. This study is significant due to the lack of discussion on literature in the form of digital especially from the perspective of creation using the latest technology. Most discourse or debate on this issue revolve around text analysis or criticism using specific theories or it involves text analyses from the extrinsic and intrinsic point of view. This research is different because it does not deal with only the internal aspect of a literary work: it also takes into consideration the technology used in creating the latest literary work since the need for new literary dimension is pressing.

\section{Literature Review}

Research regarding smartphone application for literature is still in its infancy since it is considered as new and knowledge in this field of technology becomes available only recently. In Malaysia, studies on book publication such as e-book or digital book are mentioned in several articles such as a study by Fadli Ishak and Md. Sidin Md Abdullah (2016). However, this study did not focus on the process of producing literary text via digital platform. Several international studies such as those from Indonesia discussed the use of Wattpad in the process of creative writing that is relevant to this study. One of them is Dina Purnama Sari (2017) who studied authors who used the application (Wattpad). In addition, another study was conducted by Shaharani and Mahadian (2017) focused on the Fan Fiction writers in Wattpad application. Moreover, the researcher also reviews the research on Kindle which specifies on reading. A study by Stevens (2012) discussed the different issue of book reading pattern in the future which involves a digital platform. This research differs from the previous ones because it aims to study different applications which could be used by the authors and readers.

\section{Methodology}

This research is an initial study which utilizes the observation method through a digital space which specifies resources through smartphones. In this case, the research is conducted by analyzing applications offered in smartphones for the author's use in the process of producing creative writing materials such as novel, poems, screenplay and others. Research is not 
limited to only Malay-based application but it also incorporates research for relevant international applications which are suitable to be used in literature. For this study, research scope is, it involves existing applications and the researcher will not delve deeper into each one of them.

\section{Significance of Research}

Studies on smartphone applications have been discussed in many articles but specific research on application for local literature is rather limited. Malaysia, experts in this field are scarce since many studies emphasize on theories found in literary texts. This study, therefore, is considered as crucial since it fills in the gap in digital literature research of which most efforts are focused on creative processes through the use of specific mediums : in this case, studies revolve around providing information to the users on the availability of applications for creative writing materials in smartphones.

\section{Smartphone Technology}

What is a smartphone? Not limited to a mobile phone, it functions as a platform for mobile computer system (Mohamed, Fatah \& El-Den, 2014, pg. 4). Like other mobile phones, smartphones enable users to make calls and send messages. However, being further developed, smartphones offer touchscreen which is sensitive to finger touch, functional camera, accessibility to Internet that allows users to send information, socialize, play games and others. Malaysian Communication and Multimedia Commission (MCMC) defines smartphone as;

A mobile handset that is used as the person's primary phone device which has capabilities to perform Internet-based services and function like a computer, including having an operating system capable of downloading and running applications, also those created by third-party developers (pg. 9).

Whenever new technology will come it will affect the life style of people. In a very short time mobile phones have changed the way people communicate with each other (Sarwar \& Ghafoor, 2014). Mobile phone evolution history began in 1973 and communication development has rapidly ascended since then. Mobile phone transformation continues to develop not only in its physical form which was once bulky, heavy and expensive but it also underwent major functional change. Previously, a mobile phone functioned as a communicational tool that received calls transformed when text messaging or known as SMS was introduced. It evolved to be further advanced when Internet came into the picture. Since then, the function of a telephone has taken over human's life system by offering media convergence that is inclusive of information at one's fingertips, entertainment, social interaction among humans through social media and the list goes on. Smartphone's popularity soars when everyone from different age groups and walks of life own one.

Based on this situation, computer companies begin to offer the best state-of-the-art smartphone. From Nokia, Sony Ericson, HTC, Blackberry and today, more well-known brands emerge such as iPhone, Samsung, Huawei, Oppo, Vivo, Alcatel, LG and others are produced in series. Some of them come with Tabs and Notes collection. From this point onwards, more companies compete with one another in producing lucrative applications that become part of the package in a smartphone purchase. Among popular applications are WhatsApp, 
Instagram, Wechat, Telegram and others which are used worldwide. In addition, there are thousands other applications that come together with their own functions. These are inclusive of applications which can be used in the field of literature. Looking back the origin of an application, Amazon.com in 2012 had launched Kindle Fire and later Kindle Fire HD. The introduction of this application was a huge contribution to the history of electronic literary texts. Kindle enables readers to easily search, store, purchase, download and read materials through e-book and the latest development of this application allows readers to produce their own e-book through Kindle Direct Publishing. In 2009, as a promotional stint for Kindle 2, Stephen King wrote his novel entitled UR through Kindle Store access.

Today, there are many applications which are specifically designed and indirectly can be utilized for creative purposes. All these applications are installed in the smartphone to make it convenient for the users to store and use it without computers. Cellular phone technology could be one of the major catalyst in bringing the developing world into modern age (Griffin, 2013).

The number of smartphone users increases exponentially each year. It is predicted that the amount will soar in line with the introduction of Fifth Generation (5G) phones, equipped with advanced technological features. In 2019, it is believed that the number of smartphone users will reach 2.7 billion and Malaysia has the highest percentage at 11 million, putting it at the $10^{\text {th }}$ in the world for smartphone ownership (MCMC, 2017, pg. 11). Thus, it is not surprising at all when thousands of applications are already installed in smartphones with the latest, advanced features.

There are three main operational systems in a smartphone namely Google Android, Apple iOS and Windows Phone. All three systems provide different functions with their own unique operation system. They also come with smartphone models with varying unique functions. Telstra.com explains that Android is the most popular mobile phone operation system which is favored by many/hundreds of mobile phones are produced using this operation system. In fact, numerous Android applications are given for free as compared to Apple iOS. iPhone was produced by Apple in 2007 and it topped the chart in smartphone technology market (Chatrand, 2016).

\section{Application}

According to Kerris and Muller which was cited in the IST Africa proceeding, 'smartphones run Operating Systems (OS) that allow the installation of third party dan vendor applications or "Apps". Most Smartphone OS' have their own dedicated Apps that are normally available from a portal for downloading, frequently referred to as an "App Store" (2012). Application is a software which presents certain functions to the users (Douglas \& Melody, 2012). The term app is extremely popular in mobile devices such as iPhone, iPad, Android and other smart devices. App is often accessed by pressing on the icon on smartphone main screen without having to go through a program or website address and it is very easy to be used (Ghuloum \& Al-Lamki, 2017). A study by Suciartini \& Sugiharni (2018) claimed that;

The development of digital literature is very worth considering as a space for appreciation and dissemination of alternatives to literary works in the information technology era. Reading literary works through iPad, tablet computer, Kindle, or smartphone, besides growing lifestyle, currently it is 
growing into its own creative-digital industry. Digital literature will be an alternative that many people like.

Literature in the digital world provides space and easy access for an individual to be creative. Various applications are created to allow an author to utilize all facilities provided in the digital space. In a smartphone, for instance, there are many applications designed to assist an author to write. In conventional writing, the author usually writes on a paper or in a notebook before transferring it into the computer. Today, applications are available in tablets, computers or smartphones that enable authors to write directly in it. Several applications or also known as 'apps' are specifically created for authors to fully utilize them as a medium. They assist the authors to work on their writing wherever they are without having to carry a conventional medium to jot down. Of late, Internet users prefer simple and fast platform as well as one that is accessible to many people. The best example of this characteristic can be found in the Instagram. Instagram allows each individual to be artistic through photography without its basic knowledge. Its preparation is made easy by pressing the camera button, upload the pictures into the application and various tones are ready to be applied on these pictures prior to publishing it. In fact, the pictures are posted for followers to see and feedbacks are given immediately after they are shared. The same concept applies for other applications which are created for the benefits of the field of literature. Below are explanations for several categories which are commonly offered to literary authors and readers. Some of these applications are free of charge and others have to be paid for maximum usage.

\section{Creating Application}

Application for creation is produced specifically for authors who wish to write a literary text by applying a variety of multimedia. Basically, the authors are able to plan their writing well, put the process in order, make their efforts simple and fast because these applications can be directly accessed through smartphone or tablet. For instance, applications in novel genre emphasize the method to write a novel using templates provided. Next, the applications enable readers to download the novels given. The authors could plan their chapters, arrange chapters or plot, keep and develop ideas until they are utilized to create a complete novel which could later be shared with the users through the same application or other medium. Application users have these facilities so that they do not have to carry papers around or write on something which could later be misplaced. Ideas could also be easily explored when they emerge since these applications allow users to keep the files which can be accessed through the same account in many different devices such as smartphone, tablet or computers. The functions of papers, tissues or other tools which authors have previously used are taken over by these applications.

In novel writing, the common 'apps' provided attempts to ease the users to write chapter by chapter by providing sections of specific templates. Several applications that can be accessed are Wattpad, Werdsmith, How to Write a Novel, Creative Writing, Novel Idea, Evernote, Google Docs and many others. Users could choose suitable apps since they usually offer applications with almost similar functions. They might be different in terms of user friendliness, easier and attractive icons, beautiful graphics and others but eventually they lead to the production of a text. Some of these apps provide various functions for example, Werdsmith offers typing functions for authors to write novel, poems and screen play. For those who would like to write all three materials, they do not have to use different applications since these could offer the best functions. 
Some of the popular apps today for Android users are IA Writer, Mono Space, Writer Plus, Jotter Pad, Novelist, Text Maker and others. As for iPhone users, iPad dan Mac they could use Byword, 1Writer, Editorial, Ulysses, Werdsmith, Pages and others. Some of these applications can be used by any operation system. Among suitable apps for both popular operation system are Scrivener, Evernote, Audible, Wattpad and the list goes on.
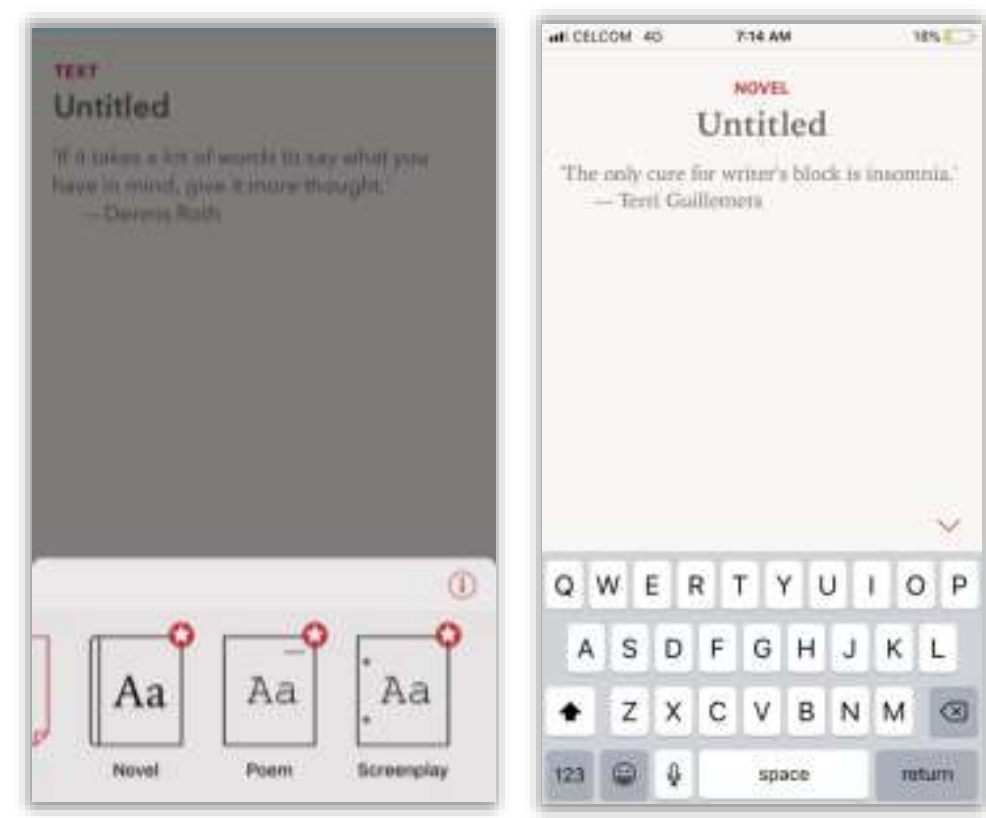

Figure 1: The Screen Shot of the novel writing app, Werdsmith.

There are different characteristics between the applications offered. Some of them could be divided into these features.

1. Write certain literary text

2. Write several genres in once application such as novel, poems or screen play.

3. Write by choosing backgrounds such as graphics, video and sounds

4. Write together (collaborative writing)

5. Write and submit text

6. Write and create book cover

More interesting thing in the use of applications is that it makes it easier for users to generate ideas. For example, Writing Prompt by Bew is able to assist authors to find prompts, deal with writers' block or lack of ideas since this application offers more than 700 stock of prompts, 500 or more first liners as well as more than 100 prompts from other users which could be used to assist the process of producing a text. More interestingly, there are applications which help the authors to avoid disruptions while writing by putting some functions such as Focus Writer. Such application enables authors to only face document screen by covering all other tools which appears on the computer screen.

In poetry writing, several applications could be accessed in the smartphones such as Poetics, Instant Poetry2, Social Poetry, Verses Poetry, Poetreat and others which enable the authors to utilize various multimedia features such as graphic, text colors or many kinds of 
alphabets, include background for poetry texts to make it more interesting and appealing to the readers compared to conventional poetry writing that offers unattractive, common texts.

\section{Reading Applications}

Applications which are categorized as anthology are those which gather the text produced by others. These written materials could be read if a person downloads the applications into a computer, smartphone or tablet. Some examples for these types of applications are Poetry Daily, Poetry, Famous Poetry, World Poetry, Poem Hunter, Steller and many more. These applications, however, depend on the capability of a smartphone software, tablet or computer. Some software does not allow these applications to be downloaded. Users must pay first before they could access them. There are applications which could be accessed by Android but are not available for iOS for several reasons set by the companies.

Specifically, reading applications are mainly provided by communication companies to enable users to download stories by being the reading hub in the internet. Some of the applications are Aldiko, BookFunnel, Wattpad, Prolific Works and the list goes on. Among them are applications which allow the users to download reading materials for free but users have to pay for book subscription such as Audible, iBooks, Kindle, Nook, Kobo and others. Some of these reading applications enable the users to write and submit their texts.

\section{Applications in Malay Literature}

Among the diverse applications available online today, most of them emphasize on the use of English as the main language medium since the developer and creator of these applications mostly originate from the West. Hence, its function is unsuitable for readers who are not familiar with a foreign language, more interested in reading in Malay as well as interact with local readers or those in the same category. Specific application in Malay is scarce since its usage is also limited. Some of the applications which could be used by those who are from the Malay regions are Storial and E-Sentral but these applications are mostly produced in Indonesian language because they are founded by companies from there. One application which is created in Malaysia is known as Novel Plus and it is fully written in Malay. Written texts could also be accessed via Wattpad since this application has more than 50 languages and Bahasa Melayu is listed among them. Nevertheless, the development of novel writing in Malaysia in the digital world started to gain momentum when novels are written through Penulisan2U and Karyaseni which have their own followers and numerous texts to offer. Both written platform however, could be accessed through Wattpad application. Recently, Karyaseni is upgraded using its own application known as Karyaseni application which can be downloaded through Google Play and Karyaseni Mobilea Apps through App Store.

\section{Conclusion}

Knowledge on applications which contributes to the development of literature is scarce and seldom gets the attention of literary enthusiasts. Through this article, researchers will find various interesting applications as discussed in the above topics. These applications help the authors to work with ease as the applications provide user-friendly features for the authors as well as making it easier for the readers to access the reading materials. Moreover, the same applications enable the authors to market their work without having to go through the processes of editing and endless waiting for publication: feedback can be obtained directly from the readers too. 
Technology does not necessarily produce quality piece of writing to an author. Wellknown authors before the emergence of digital technology relied on limited knowledge, nonadvanced equipment, as well as limited ability. However, they were able to produce esteemed written materials that were famous and subjects of discussions. Technology, at the same time, must not be completely dismissed since time has changed, the market demand is different and facilities are readily available. It is undeniable that the literary field needs better technology to propel literary texts forward. In this situation, facilities provided in the smartphones are extremely useful for authors to come forward, be independent from the third party which gives complications and bureaucracy. Smartphone is also a means to expose the author's unique creativity. Digital technology development remains positive and useful as it is an advantage. Furthermore, with the presence of many applications in the smartphones, the authors are assisted in producing more quality literary materials since everything is at their fingertips.

Based on this article, several studies on applications must be brought forward through literary criticism since existing paper are rather limited especially locally. Several future studies which could be explored are specific research on Malay application which enables users to obtain accurate knowledge in the aspect of creation, production, marketing and publication of literary work through this method. In addition, this research is crucial to application developers in their pursuit to create applications which offer better features, more functions, user-friendly and accessible to all.

\section{References}

Abdullah, F. \& Ishak, M. S. (2016). "Kesan Perkembangan Teknologi Terhadap Industri Buku di Malaysia." Malaysian Journal of Media Studies, 18(2). Retrieved from https://jpmm.um.edu.my/article/view/5711/3451

Chartrand, R. (2016). Advantages and Disadvantages of Using Mobile Devices in a University Languages Classroom. Retrieved from https://swsu.ru/sbornikstatey/pdf/gaiken23_1-13.pdf

Douglas, D., \& Melody, C. (2012). Dictionary of Computer and Internet Terms, $10^{\text {th }}$ Edition. Barron's Educational Series. Retrieved from https://inspirit.net.in/books/misc/Dictionary\%20of\%20Computer\%20\&\%20Internet \%20Terms.pdf

Griffin, H. (2013). "Has Mobile Phone Technology Had an Impact on the Quality of Life in the Developing World?" International Journal of Academic Reseacrh in Business and Social Sciences, 3(7). Retrieved from

http://hrmars.com/hrmars_papers/Has_Mobile_Phone_Technology_Had_an_Impac t_on_the_Quality_of_Life_in_the_Developing_World1.pdf

Ghuloum, H.F. \& Al-lamki, Z. (2017). "The Utilisation of Smartphones Apps as a Service Tool at Kuwaiti Academic Libraries". Informing Science: The International Jounal of an Emerging Transdicipline, vol 20. Retrieved from http://www.inform.nu/Articles/Vol20/ISJv20p133-148Ghuloum3198.pdf

Mohamed, M. A., Fatah, A. I \& El-Den, B. M. (2014). "Development of Multimedia Application of Smartphones". International Journal of Computer Application, 95(2). Retrieved from https://pdfs.semanticscholar.org/da44/8a1d037f9dcd3e41a752d60df7d28df3c74b.p df 
Suciartini, A. N. N., \& Sugiharni, D. G. A. (2018). "Pelatihan Penggunaan Bahasa Ibu dalam Karya Sastra Digital". Widyabhakti Jurnal IImiah Popular, 1(1). Retrieved from https://widyabhakti.stikom-bali.ac.id/index.php/widyabhakti/article/view/22

Salleh, A. R. (2016). "Meningkatkan Kegemaran Membaca dan Menulis Masyarakat". Jurnal Pustakawan Indonesia, 6(1). Retrieved from https://www.researchgate.net/profile/Abdul_Saleh3/publication/242733505_Peran an_Teknologi_Informasi_dalam_Meningkatkan_Kegemaran_Membaca_dan_Menulis _Masyarakat/links/57313c0008aed286ca0dcaaa.pdf

Sari, D. P. (2017). "Pengembangan Menulis Kreatif Melalui Wattpad". Simposium Nasional IImu Pengetahuan dan Teknologi 2017 (SIMNASIPTEK). Retrieved from http://seminar.bsi.ac.id/simnasiptek/index.php/simnasiptek2017/article/view/163/163

Suruhanjaya Komunikasi Malaysia.(2017). Hand Phone Users Survey 2017. Retrieved from https://www.mcmc.gov.my/skmmgovmy/media/General/pdf/HPUS2017.pdf

Telstra Corporation Limited. Introduction to Smartphones. Retrieved from https://www.telstra.com.au/content/dam/tcom/seniors/pdf/beginners-introsmartphones.pdf

UYS, W., Josias, M. A., Khusus, M., Gierdien, M., Mia, A., Jansen, G. J., Schyef, V. D. H., Leukes, N. A., Falten. S., Gihwala, T., Theunissen, T. L., Samsodien, Y. (2012). "Smartphone Application Usage Among Students at a South African University". IST-Africa Conference Proceedings. Retrieved from http://www.istafrica.org/home/outbox/ISTAfrica_Paper_ref_60_doc_4812.pdf

Wahla, R. S. \& Awan, A. G. (2014). "Mobile Phones Usage and Employees' Performance: A Perspective form Pakistan". International Journal of Academic Reseacrh in Business and Social Sciences, 4(4). Retrieved from http://hrmars.com/hrmars_papers/Article_15_Mobile_Phones_Usage.pdf 